\title{
Characterization of Indonesia wild honey and its potential for authentication and origin distinction
}

\author{
${ }^{1,3}$ Riswahyuli, Y., ${ }^{2}$ Rohman, A., ${ }^{1}$ Setyabudi, F.M.C.S. and ${ }^{1}$ Raharjo, S. \\ ${ }^{1}$ Department of Food and Agricultural Product Technology, Faculty of Agricultural Technology, \\ Universitas Gadjah Mada, Jl. Flora 1, Bulaksumur, Sleman, Yogyakarta, Indonesia \\ ${ }^{2}$ Faculty of Pharmacy, Universitas Gadjah Mada, Yogyakarta, Indonesia \\ ${ }^{3}$ Indonesia Food and Drug Authority (BPOM RI), Jakarta, Indonesia
}

Article history:

Received: 12 March 2020

Received in revised form: 13

April 2020

Accepted: 14 April 2020

Available Online: 7 June

2020

\section{Keywords:}

Wild honey,

Physicochemical,

Sugar,

Mineral,

Antioxidant

DOI:

https://doi.org/10.26656/fr.2017.4(5).105

\begin{abstract}
Honey is a natural food derived from flowers nectar that has many health benefits. This reason made honey become one of category food product that has a risk to be adulterated because of economically motivation. This study was conducted for characterization and authentication of Indonesia wild honey (IWH) collected from seven geographical regions (Sumatra, Bangka Belitung, Java, Kalimantan, Sulawesi, West Nusa Tenggara, and East Nusa Tenggara) and harvested during 2016-2018 based on physicochemical parameters, sugar content, minerals, and antioxidant components. The study showed that the result differs widely among the type of honey. IWH has a moisture content between 16.52$33.41 \%$, a pH value between 3.00 to 4.65 and color characteristic ranged from pale yellow to dark brown. All samples contain the highest amount in potassium, but several minerals found in the specific region. Evaluation of authenticity from sugar content data set by principal component analysis (PCA) and Linear Discriminant Analysis (LDA) revealed that the authentic and adulterated honey samples could be differentiated with a $95.5 \%$ accuracy. The honey samples were classified on their botanical and geographical origin using the antioxidant properties, and results of PCA and LDA demonstrated that the antioxidant parameters can provide adequate information to allow classification of the various types of IWH samples collected from different geographical regions with accuracy $80-100 \%$ for Bangka Belitung, Sulawesi, Kalimantan, West Nusa Tenggara, East Nusa Tenggara and Java island.
\end{abstract}

\section{Introduction}

Honey is a natural product obtained by honeybees from nectar or honeydew. It has been used as a valuable diet and medicine since ancient times. The medical and nutritional properties of honey have elicited increasing interest in extensive scientific research conducted in recent decades (Alvarez-Suarez et al., 2010; Horn, 2013; Al-Waili et al., 2013; Saranraj and Sivasakthi, 2018). In general, honey consists of sugar, water, and other substances such as proteins (enzymes), phenolic compounds, organic acids, pigments, vitamins, minerals, various volatile compounds, and solid particles (Pereira et al., 2008; Alqarni et al., 2014; da Silva et al., 2016). The different properties of honey are associated with the various compounds derived from honey bees and plant sources, such as enzymes and phenolic compounds (Lachman et al., 2010; Kuś et al., 2014). Some of the properties of honey can confirm the quality and authenticity of honey and find similar characteristics in different types of honey using requirements such as purity, maturity, and deterioration (Silva et al, 2016). Honey can also be used as a bio monitor to provide information related to the environment where the bees live. Bees have contact not only with air but also with land and water, and the concentration of heavy metals such as lead and cadmium in honey could reflect the number of components present in the entire region (Ioannidou et al., 2005; Silici et al., 2008). Therefore, honey has been recognized as a biological indicator of environmental pollution.

The concentration of sugar in honey is generally approximately $83^{\circ} \mathrm{Brix}$, or approximately $83 \%$ sugar (Ball, 2007). Depending on the source of honey, climatic conditions, and other factors, the moisture content of honey varies from $13.6 \%$ to as high as $23 \%$. Fermentation is a natural process occurring in honey that 
can reduce its moisture content to $<18 \%$. Honey is acidic, but its high sugar content can suppress this taste; the average $\mathrm{pH}$ of honey is 3.9 (Ball, 2007). Another distinctive property of honey is its color. Mass-produced honey is a mixture prepared from several sources, so that it might a uniform color. However, individually harvested honey could have various colors depending on the season, the source of nectar, the age of honey (time between nectar collection and honey harvesting), and the product handling method after harvesting. Some researchers have argued that there are several possible factors responsible for the color variations of honey, such as carotene compounds, polyphenols, chemical caramelization of saccharide in the honey, and Maillard reaction between sugars and amino acids. However, the fact is whatever the source of the color, the darker the honey, the stronger the taste (Ball, 2007).

Limited availability and high price of a particular type of honey will generate economically motivated adulteration in honey products. Currently, the major concerns related to the authenticity of honey are focused on the geographic and botanical origin, but the addition of other substances that are generally not permitted, such as syrup and sugar, is also an important issue. Adulteration in terms of production includes the addition of sugar, thermal processing, and activities related to modifying its moisture content. The practice of counterfeiting such as feeding bees excessively with sucrose or other commercial sugars, harvesting before maturity, and the excessive use of veterinary drugs is still followed by some manufacturers around the world to meet the market demands (Bogdanov et al., 2004; Sahinler et al., 2004; Guler et al., 2007; Soares at al., 2017).

Previous studies have used existing information to develop authentication techniques combined with chemometrics due to certain positive aspects as follows: Minimal sample handling that would minimize the risk of contamination and problems associated with the viscosity of the sample. Rapid and simple. No need for a quantification process that involves creating a calibration curve. Determining the authentication of honey requires more than one variable such as the correlation among physicochemical properties (Corbella and Cozzolino, 2006; Yücel and Sultanoğlu, 2013), physicochemical properties and volatile components (Karabagias et al., 2014) and the antioxidant properties with mineral content (Alves et al., 2013), which requires performing multivariate analysis. In fact, an earlier study had used multivariate analysis in chemometrics to determine the variables having a high discriminant ability that contributed to the classification of honey (Nalda et al., 2005)
Wild honey is produced in the forest by the bee Apis dorsata that feeds on the flowers of the forest trees and forms a nest on the branches of trees (Sarwono, 2003). A. dorsata is the largest among other honey bee species. This species is grown only in the subtropical and tropical Asian countries such as Indonesia, the Philippines, India, and Nepal and is not found out of Asia. This bee is the most productive in producing honey compared with other species, which constructs a single vertical comb that hangs on the branches and twigs of trees, open ceiling, and the cliff rocks. Indonesia wild honey (IWH) is generally known by names of a local origin, i.e., Sumbawa Honey, Pontianak Honey, Riau Honey, Flores Honey, Gunung Mutis Honey, Tessonilo Honey, and Lake National Park Sentarum. According to a study conducted by Sari and Bertoni (2014), some wild honey in Indonesia has various antioxidant and anticancer activities depending on the region. In the present study, we describe the results of the analysis of IWH and its properties and about the authentication process using the properties of honey. A number of previous studies have published multivariate techniques for honey authentication (Sivakesava and Irudayaraj, 2001; Nalda et al., 2005; Downey and Kelly, 2006; GallardoVelázquez et al., 2009; Siddiqui et al., 2017; Zhou et al., 2017; Boussaid et al., 2018; El-Haskoury et al., 2018; Ma et al., 2019). We believe that this study is important in identifying the differences in IWH and the previously investigated honey samples and in expanding the methods to tackle the problems of national-scale adulteration and mislabeling of honey in Indonesia.

\section{Materials and methods}

\subsection{Samples and sampling}

Honey sample was collected from 2017 to 2019 from 7 different forest areas, including Sumatra (Tesso Nilo, Riau and Gunung Kerinci National Park, Jambi), Bangka -Belitung (Pelawan Tourism Forest, Namang, Bangka Tengah, and Belitung Island), Java (Ujung Kulon National Park/Panaitan island, Banten), Kalimantan (Sentarum Lake National Park, Kapuas Hulu, West Kalimantan), West Nusa Tenggara (NTB; Sumbawa subdistrict, West Nusa Tenggara), East Nusa Tenggara (NTT; Muntis Mountain Conservation, South Central Timor and Maumere, Flores Timor), and Sulawesi (North Morowali, Central Sulawesi, Manado, North Sulawesi, and Tulak Tallu village, North Luwu, south Sulawesi (Figure 1)). Their authenticity and freshness were assured by collecting them directly from the forest areas, local beekeepers under the Indonesia Wild Honey Association Once received, honey samples were stored in clean, closed jars at room temperature and in the dark until use. Additionally, some honey samples were purchased from Indonesia Wild Honey Network, which 
guarantees authenticity. The adulterated honey samples also prepared by adding of commercial sugars in Indonesia (aren, palm, and cane sugar solutions).

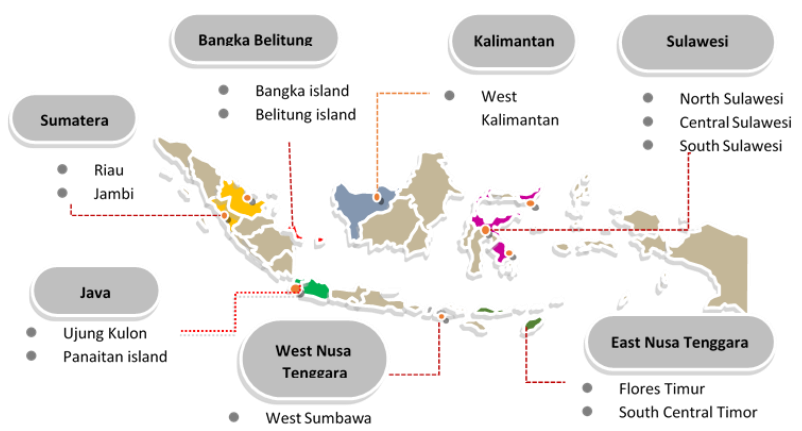

Figure 1. Indonesia wild honey source regions

\subsection{Physicochemical analysis}

\subsubsection{Determination of color}

The determination of color was carried out as described by Karabagians et al. (2014). Honey solution (10 g in $75 \mathrm{~mL} \mathrm{CO}_{2}$-free water) was taken in an optical cylindrical cell (base diameter $11.3 \mathrm{~cm}$ and height $2 \mathrm{~cm}$ ). The parameters of color: $L^{*}, a^{*}, b^{*}\left(L^{*}\right.$ indicated Light/ bright, $\mathrm{a}^{*}$ indicated the coordinates of the red/green, and $b^{*}$ indicated the coordinate of yellow/blue) measured by colorimeter Chroma Meter CR 410, Konica Minolta, Tokyo, Japan.

\subsubsection{Determination of moisture content}

The moisture content was determined using a refractometer (N3 Atago, Japan) at a temperature of $20^{\circ}$ $\mathrm{C}$ on the basis refractive index using Chataway Charts through the formula:

$$
W=\frac{1.73190-\log (\text { R.I- }-1)}{0.002243}
$$

$\mathrm{W}$ is the moisture content in $\mathrm{g}$ per $100 \mathrm{~g}$ honey and R.I. is the refractive index (Stefan, 2009)

\subsubsection{Determination of $\mathrm{pH}$}

$\mathrm{pH}$ was measured at levels of $10 \%$ of honey solution in water using a $\mathrm{pH}$ meter (Mettler Toledo, Ohio, US) (Bogdanov, 2009).

\subsection{Determination of the content of minerals and metals}

The concentrations of various minerals and metals, lithium, beryllium, boron, potassium, magnesium, aluminum, potassium, calcium, chromium, manganese, iron, cobalt, nickel, copper, zinc, gallium, selenium, strontium, cadmium, tellurium, barium, mercury, thallium, lead, and bismuth were measured using inductively coupled plasma mass spectrometer (ICP-MS) Agilent 7700 single quadrupole, with helium and no gas modes (Batista et al., 2012). Before analysis, the honey samples were homogenized by agitation and heating at a temperature of $65^{\circ} \mathrm{C}$ in a water bath for 30 mins to dissolve the sugar crystals contained in the honey. Then, $1 \mathrm{~g}$ of the homogenized honey was weighed accurately and $1 \mathrm{~mL}$ demineralized water was added and shaken (deionized water of $18 \mathrm{M} \Omega \mathrm{cm}^{-1}$ resistivities, obtained from a Milli-Q system (Millipore), was used to prepare all solutions). Next, $0.4 \mathrm{~mL}$ of the honey solution was transferred to another container and $0.2 \mathrm{~mL}$ of $14 \mathrm{~mol} / \mathrm{L}$ $\mathrm{HNO}_{3}$ (Merck) was added and incubated for 20 mins. This was followed by adding $10 \mathrm{~mL}$ of demineralized water and measuring using the Agilent ICP-MS. Mineral concentration in the honey determined by comparing with the standard curve using a mix of minerals and metals (ICP multi-element standard solution XXI for MS Certipur®, MerckMilipore) $(0.1-25 \mathrm{ng} / \mathrm{mL})$.

\subsection{Statistical and multivariate analysis}

Data processing was performed using Minitab ${ }^{\circledR} 18.1$ (Minitab Inc., State College, Pennsylvania, USA). The Pearson correlation was calculated to determine the relationship properties. The level of significance was set at $\mathrm{p}<0.05$. Unsupervised and supervised pattern recognition techniques such as PCA and LDA were used to visualization and discrimination between authentic and adulterated honey or between honey samples of different floral origin.

\section{Results and discussion}

\subsection{Physicochemical properties}

\subsubsection{Color}

The results of color analysis of the wild honey samples collected from seven regions in Indonesia demonstrated high variability ranging from a light tone to an almost black yellow tone, with the $\mathrm{L} *$ value in the range of 43.65-59.77, the $b *$ value in the range of 1.28 7.69 , and the $\mathrm{c} *$ value in the range of $0.19-14.26$ (Table $1)$. Color is one of the most varied parameters, and it is primarily determined by the floral origin. It also depends on the ash content, the temperature when honey stored in the honeycomb, and the storage time (Bertoncelj et al., 2007; Gámbaro et al, 2007). In this study, based on the region of origin, it was observed that the honey collected in Java had a degree of variation of $\mathrm{L}$ with the lowest value, and the honey in this area was brightly colored compared to some of the darker honey samples collected from areas such as Bangka Belitung and Sulawesi. Boussaid et al. (2018) evaluated six honey samples collected from different areas of Tunisia and found the values of light ( $\left.\mathrm{L}^{*}\right)$ ranging from 36.64 to 51.37 . Color is the first component of interest of honey and a very important parameter in terms of quality, perception, and preference of the consumer. Color measurement made by colorimetric technique using a standard CIE L $* a * b *$ 
Table 1. Physicochemical parameters of Indonesia wild honey

\begin{tabular}{lccccccccc}
\hline \multicolumn{10}{c}{ Sample Origin } \\
\hline Parameters (Mean) & $\begin{array}{c}\text { Bangka- } \\
\text { Belitung }\end{array}$ & Sulawesi Kalimantan & Sumatera & $\begin{array}{c}\text { West Nusa } \\
\text { Tenggara }\end{array}$ & $\begin{array}{c}\text { East Nusa } \\
\text { Tenggara }\end{array}$ & Java & Average & Range \\
\hline Color & & & & & & & & \\
L* & 54.47 & 53.31 & 55.46 & 50.8 & 52.56 & 53.62 & 58.5 & $54.10 \pm 2.25$ & $43.65-59.77$ \\
$\mathrm{a}^{*}$ & 3.46 & 2.22 & 2.34 & 3.23 & 2.5 & 1.99 & 0.08 & $6.36 \pm 4.02$ & $1.28-7.69$ \\
$\mathrm{~b}^{*}$ & 3.46 & 8.82 & 7.44 & 13.74 & 2.98 & 7.24 & 0.82 & $2.57 \pm 0.51$ & $0.19-14.26$ \\
Moisture content (\%) & 29.2 & 19.75 & 19.14 & 20.76 & 26.76 & 24.2 & 24.33 & $24.84 \pm 4.12$ & $20.32-31.9$ \\
pH & 3.96 & 3.89 & 3.92 & 3.75 & 4.42 & 4.01 & 3.86 & $3.75 \pm 0.71$ & $3.08-4.65$ \\
\hline
\end{tabular}

or sometimes abbreviated simply as "Lab color space." In 1976, the International Commission on Illumination (CIE) had defined CIELAB color space expressing the following three values: $\mathrm{L} *$ for light from black $(0)$ to white $(100), a *$ for green $(-)$ to red $(+)$, and $b *$ for blue $(-)$ to yellow $(+)$. In practice, space is generally mapped to the integer of three-dimensional space to a digital representation, and thus the values of $\mathrm{L}^{*}, \mathrm{a} *$, and $\mathrm{b} *$ are generally absolute, with a range that has been predetermined. In several countries, the price of honey is associated with a color. In general, light-colored honey has a higher price, although dark honeys are appreciated in certain areas (Tuberoso et al., 2014). The dark color of honey might develop during storage and might also be associated with storage temperature and composition of the honey. In a correlation study of IWH, the color appeared to have a significant correlation with flavonoid content (Table 2), this might the reason why honey from Sumatera or Sulawesi are darker than Kalimantan or Java. IWH from Sumatera or Sulawesi has total phenolic content and total flavonoid content higher than IWH from Java or Kalimantan (Riswahyuli et al., 2019).

\section{$3.1 .2 \mathrm{pH}$}

Natural honey are acidic with a $\mathrm{pH}$ value in the range of 3.5-5.5, which is caused due to the presence of organic acids that contribute to the taste of honey and provide protection against microbes (Bogdanov et al., 2004). The $\mathrm{pH}$ of IWH in this study ranged from 3.00 to 4.65 , with an average of $3.75 \pm 0.71$. Due to the low $\mathrm{pH}$ variation between regions, this parameter could not be used for distinguishing the types of honey; however, this study showed that adulterated honey has a higher $\mathrm{pH}$ value than authentic honey (Table 1).

\subsubsection{Moisture content}

Moisture content is one of the most important characteristics that affect the physical properties of honey such as viscosity and crystallization and other parameters such as color, taste, specific gravity, and solubility (Escuredo et al., 2013). The moisture content of IWH ranged from 20.32 to 31.9 , with an average value of $24.84 \pm 4.12$ (Table 1), although it exceeded the requirements set by national and international standards, the result indicates the natural condition in a tropical forest with high humidity. Another factor is rainy harvesting season, low in the degree of maturity reached in the hive and climatic factors. In this study, there is a correlation between $\mathrm{pH}$ and moisture content (Table 3) where the low moisture content makes the tendency of $\mathrm{pH}$ to be maintained low. Similar result was showed in previous studies on Nigerian honey (James et al., 2009)

Table 2. Correlations between Color, TPC, TFC, RSA, and FRAP

\begin{tabular}{|c|c|c|c|c|c|c|}
\hline & $\mathrm{L}^{*}$ & $a^{*}$ & $b^{*}$ & Total Phenolic & Total Flavonoid & $\%$ inhibition of DPPH \\
\hline \multirow[t]{2}{*}{$a^{*}$} & -0.304 & & & & & \\
\hline & 0.015 & & & & & \\
\hline \multirow[t]{2}{*}{$b^{*}$} & -0.513 & 0.279 & & & & \\
\hline & $\mathbf{0}$ & 0.025 & & & & \\
\hline \multirow[t]{2}{*}{ Total Phenolic } & -0.519 & 0.012 & 0.172 & & & \\
\hline & $\mathbf{0}$ & 0.926 & 0.182 & & & \\
\hline \multirow[t]{2}{*}{ Total Flavonoid } & -0.577 & 0.127 & 0.587 & 0.474 & & \\
\hline & $\mathbf{0}$ & 0.32 & $\mathbf{0}$ & 0 & & \\
\hline \multirow[t]{2}{*}{$\%$ inhibition of DPPH } & -0.381 & -0.097 & 0.439 & 0.434 & 0.567 & \\
\hline & 0.002 & 0.451 & $\mathbf{0}$ & $\mathbf{0}$ & $\mathbf{0}$ & \\
\hline \multirow[t]{2}{*}{ FRAP } & -0.376 & -0.016 & 0.178 & 0.368 & 0.391 & 0.084 \\
\hline & 0.002 & 0.899 & 0.163 & 0.002 & 0.001 & 0.494 \\
\hline
\end{tabular}


Table 3. Correlation between physicochemical parameters

\begin{tabular}{lccccc}
\hline \multicolumn{1}{c}{$\mathrm{L}^{*}$} & $\mathrm{a}^{*}$ & $\mathrm{~b}^{*}$ & Moisture content & $\mathrm{pH}$ \\
\hline $\mathrm{a}^{*}$ & -0.327 & & & & \\
\multirow{4}{*}{$\mathrm{b}^{*}$} & $\mathbf{0 . 0 0 1}$ & & & & \\
& -0.582 & 0.386 & & & \\
Moisture content & $\mathbf{0}$ & $\mathbf{0}$ & & & \\
& -0.079 & 0.052 & -0.033 & & \\
$\mathrm{pH}$ & 0.445 & 0.62 & 0.75 & & \\
& -0.024 & 0.134 & -0.323 & 0.305 & \\
EC & 0.877 & 0.402 & $\mathbf{0 . 0 3 9}$ & 0.044 & \\
& -0.304 & -0.129 & 0.164 & 0.145 & 0.131 \\
& $\mathbf{0 . 0 0 4}$ & 0.238 & 0.133 & 0.159 & 0.401 \\
\hline
\end{tabular}

\subsection{Minerals}

Various groups of chemicals were detected in the different types of IWH samples in this study. These chemical groups included macro minerals and micro minerals which were different compared to the results of a previous study reported by Alqarni et al. (2014). A total of 22 minerals and 3 heavy metals were analyzed to investigate the characteristics of honey in each region. Calcium was predominantly found in all regions, followed by $\mathrm{Mg}$ and $\mathrm{Ca}$ (Table 4). Fe and $\mathrm{Sr}$ were found in abundance in the Bangka Belitung honey compared with other honey samples. Mn was predominantly found in Sulawesi honey, whereas honey collected from West Nusa Tenggara and East Nusa Tenggara contained more $\mathrm{Ba}$ than in any other region. $\mathrm{Cu}$ was found in abundance in Sumatra honey than in any other region. The concentrations of heavy metals $(\mathrm{Hg}, \mathrm{Pb}$, and $\mathrm{Cd})$ in $\mathrm{IWH}$ still met the requirements. Bangka Belitung and Sulawesi honey had higher levels of B than those from other areas, $\mathrm{Mg}$ was found in honey samples collected from Sulawesi, NTT and NTB areas, Al was highly found in Bangka Belitung honey, Ca showed the least abundance in Sumatran honey, Fe was predominantly found in Bangka Belitung honey, and $\mathrm{Cu}$ was found in abundance in Sumatran honey. In general, honey reflects the chemical components of the plant from which honey bees collect their food; hence, the content of trace elements present in the honey depends on the type of soil in which plants and nectar are found and could disclose the botanical origin of the particular honey sample ( Escuredo et al., 2013; Alqarni et al., 2014; Priscila Misio da Silva et al., 2016). Analysis of Bangka Belitung honey showed that it had a higher mineral content than honey collected from other areas because of the rich mineral content in the groundwater in that area. Nalda et al. (2005) identified different minerals in honey from Spain and found a higher concentration of manganese in the honey of heather and ling. (Ajtony et al., 2007) evaluated the mineral content of honey samples from Hungary and found the least concentrations of cadmium, chromium, copper, and lead in linden honey, whereas other types of honey showed a predominance of potassium, contributing to one-third of the total of the minerals contained in honey (Yücel and Sultanoğlu, 2013; Alqarni et al., 2014). In this study, some minerals showed a correlation with other parameters. The minerals $\mathrm{Mg}, \mathrm{Cr}, \mathrm{Ni}, \mathrm{Cu}, \mathrm{Se}$, and $\mathrm{Al}$ significantly correlated with the color of honey. Previous research also reported that honey collected from fruits (avocado, chestnut, and heather) contained a number of major and minor metals and certain higher trace elements (e.g., Al, $\mathrm{Ca}, \mathrm{Cd}, \mathrm{Cu}, \mathrm{Fe}, \mathrm{K}, \mathrm{Mg}, \mathrm{Mn}, \mathrm{Na}, \mathrm{Ni}$, and $\mathrm{Zn}$ ) than pale honey; interestingly, the color of dark honey was typically related to the concentrations of $\mathrm{Cd}, \mathrm{Fe}$, and $\mathrm{Pb}$, whereas bright honey and brown-color honey were associated with the concentrations of $\mathrm{Al}$ and $\mathrm{Mg}$ (Pohl, 2009).

\subsection{Sugar}

The sugar content in honey is represented by monosaccharides glucose and fructose (Kamal and Klein, 2011). The sugar content in IWH was generally composed of fructose, followed by glucose and sucrose, except for Bangka Belitung and Sumatran honey, which contained slightly higher glucose levels than fructose. The concentration ratio between honey fructose: glucose: sucrose was approximately 1:1:0.1. Kaškoniene and Venskutonis (2010) reported that the ratio between fructose and glucose concentrations was a useful indicator for the classification of monofloral honey. Commercial sugar has a different sugar content compared with honey, in which the sucrose concentration is much higher than that in other sugars. Sucrose was found in small amounts, but this type of sugar is often added to honey and is commonly found in adulterated honey (Figure 2). In this study of honey collected from the seven regions in Indonesia, it was found that the honey could be well characterized compared with adulterated honey added with commercial sugars, as indicated by the relatively less concentration of sugar than that in the adulterated honey. However, it 


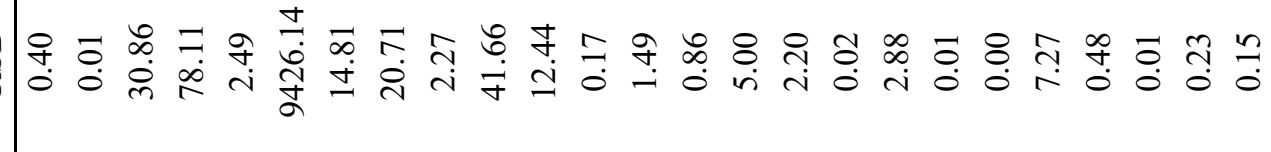

స్తి

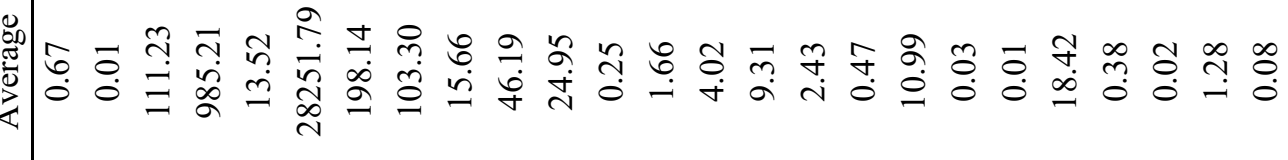

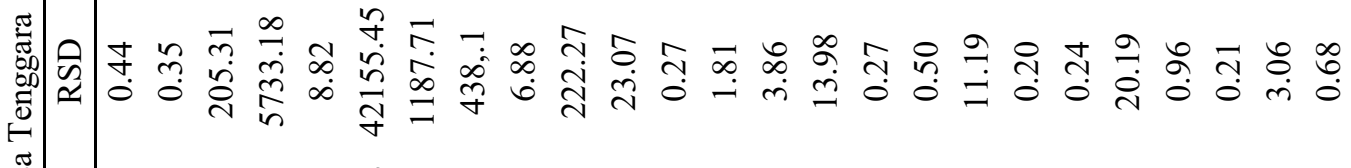

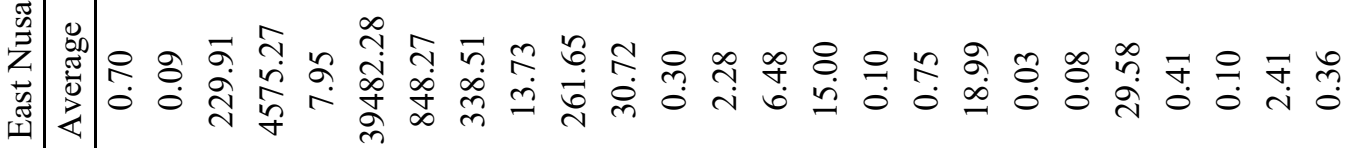

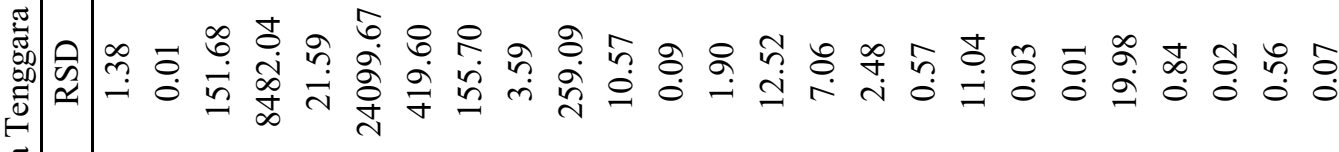

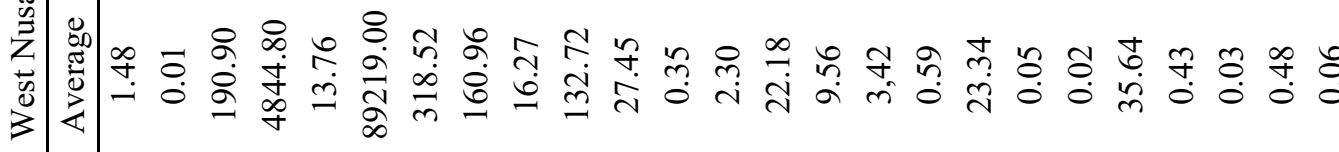

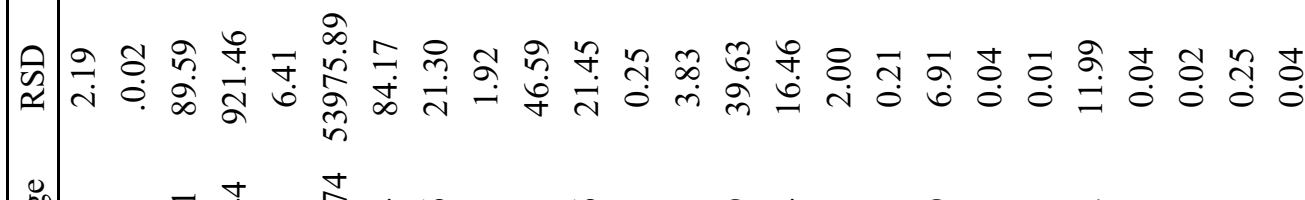

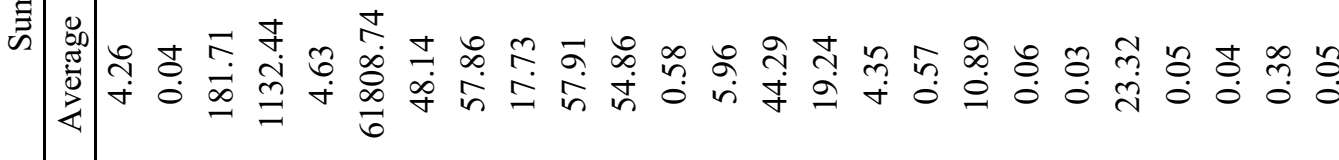

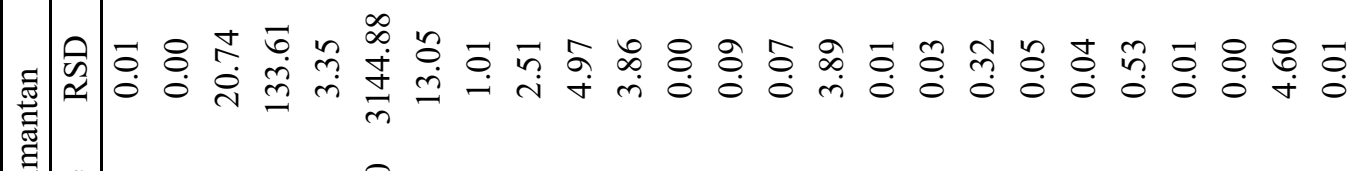

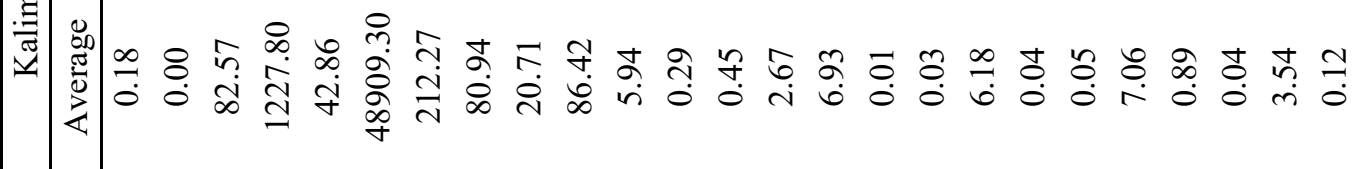

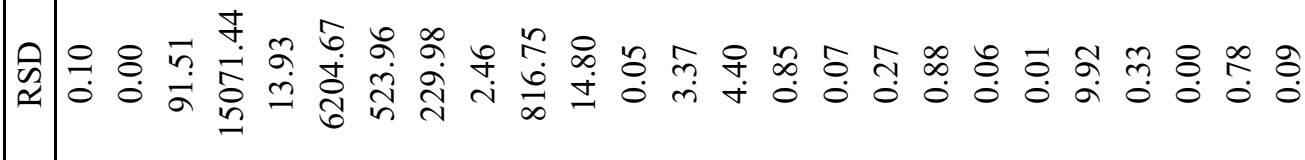

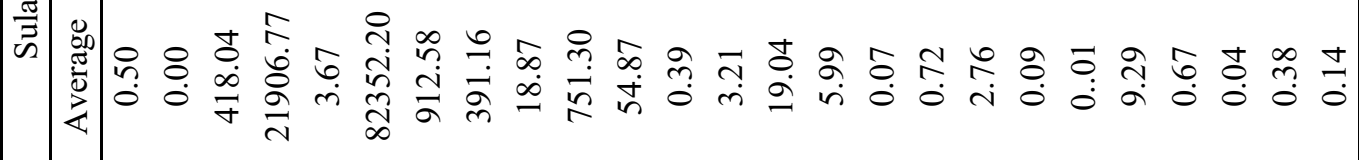

易

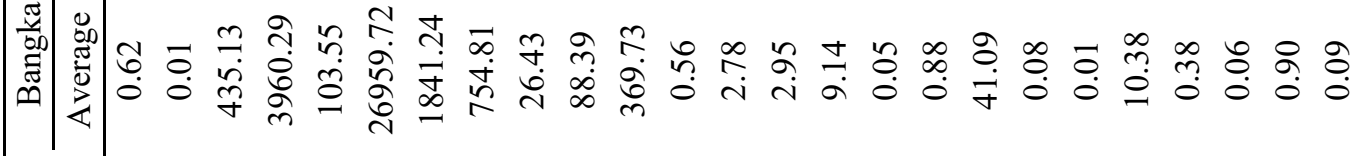

$$
\text { Ðే }
$$

चึ

造

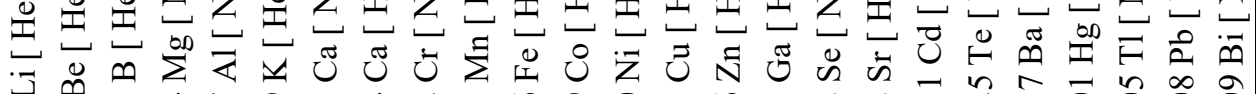

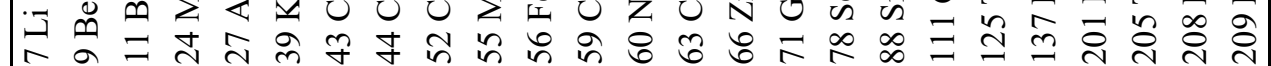


Table 5. Discriminant analysis with cross-validation for sugar content properties of Indonesia wild honey

\begin{tabular}{|c|c|c|c|c|c|c|c|c|}
\hline \multirow[b]{2}{*}{ Put into Group } & \multicolumn{8}{|c|}{ True Group } \\
\hline & Adulterated & Bangka & Java & Kalimantan & $\begin{array}{c}\text { West Nusa } \\
\text { Tenggara }\end{array}$ & $\begin{array}{c}\text { East Nusa } \\
\text { Tenggara }\end{array}$ & Sulawesi & Sumatera \\
\hline Adulterated & 42 & 2 & 0 & 0 & 0 & 0 & 0 & 5 \\
\hline Bangka Belitung & 0 & 1 & 1 & 0 & 0 & 2 & 4 & 0 \\
\hline Java & 0 & 0 & 2 & 2 & 4 & 6 & 0 & 0 \\
\hline Kalimantan & 1 & 1 & 7 & 4 & 2 & 5 & 0 & 1 \\
\hline West Nusa Tenggara & 1 & 1 & 4 & 0 & 12 & 2 & 1 & 4 \\
\hline East Nusa Tenggara & 0 & 3 & 3 & 0 & 0 & 11 & 0 & 0 \\
\hline Sulawesi & 0 & 3 & 0 & 0 & 2 & 0 & 10 & 0 \\
\hline Sumatra & 0 & 1 & 1 & 0 & 1 & 0 & 0 & 20 \\
\hline Total N & 44 & 12 & 18 & 6 & 21 & 26 & 15 & 30 \\
\hline $\mathrm{N}$ correct & 42 & 1 & 2 & 4 & 12 & 11 & 10 & 20 \\
\hline Proportion & 0.955 & 0.083 & 0.111 & 0.667 & 0.571 & 0.423 & 0.667 & 0.667 \\
\hline
\end{tabular}

was difficult to distinguish the honey samples according to the region on the basis of sugar attributes, wherein the accuracy values were $<70 \%$ (Table 5 ).

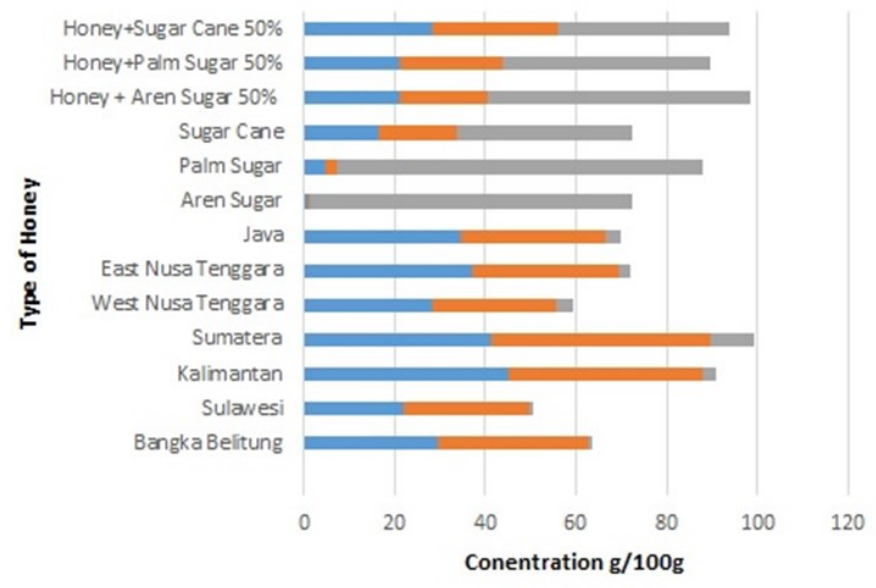

Figure 2. Sugar ( $\square$ Fructose, Glucose and $\square$ Sucrose) in honey, adulterated honey, and commercial sugar.

\subsection{Antioxidants}

Parameters of total phenolic content (TPC), total flavonoid content (TFC), and radical scavenging activity in IWH is already determined in the previous study, with result range 188.03-467.84 $\mathrm{mg}$ of gallic acid equivalent (GAE) per $\mathrm{kg}$ for TPC, $0.81-3.09 \mathrm{mg}$ quercetin (QEQ)/100 g for TFC, and 28.23-80.74\% for inhibition of RSA, a positive correlation among the three parameters based on a Pearson's coefficient of $<0.001 \%$ (Riswahyuli et al., 2019). In this study, FRAP testing was conducted based on the $\mathrm{pH}$ ability to reduce $\mathrm{Fe}^{3+}$ to $\mathrm{Fe}^{2+}$. Results of the FRAP assay of IWH showed that Bangka Belitung and Sulawesi honey had a higher yield than honey collected from other regions. The values of the potential antioxidants obtained in the FRAP test positively correlated with the total phenolic and flavonoid contents, thereby indicating that the antioxidant potential was primarily due to phenolic compounds, in this case the flavonoids, which was in accordance with the results of other studies (Lachman et al., 2010; Kuś et al., 2014). Correlation with color demonstrated that the antioxidant activity of dark honey was higher than that of light honey (Socha et al., 2011).

\subsection{Multivariate analysis}

In this study, authenticity was evaluated by multivariate analysis of chemometrics data. Previous research on IWH demonstrated the capability of FTIR spectral data to distinguish genuine and adulterated honey samples. Meanwhile, in the present study, three types of sugars (fructose, glucose, and sucrose) were analyzed, which could also be used to distinguish between adulterated and authentic honey. The principal component analysis (PCA) were showed a grouping between authentic and adulterated honey (Figures $3 \mathrm{a}$ ). It was found that three principal components (PC) explained $88.00 \%$ of the variation within the data. PC3 enabled the classification of honey into two major groups; the group shown on the right side is adulterated honey, whereas that on the left side is authentic honey. In PCA, data of the antioxidant properties were used to differentiate the honey samples according to the geographical origin (Figure 3b). LDA then was applied to explore the possibility of classifying honey samples according to the botanical origin. In LDA all variables and selected gradual variables were used to determine the accuracy of the classification into known groups, to evaluate how the predictor variables differentiated the groups, and to predict the observation of unknown groups. A summary of the classification using crossvalidation for sugar revealed that Group 1 had the highest proportion of correct placement, with $95.5 \%$ of the observations being correctly placed. Group 1 was adulterated honey; meanwhile, the results of the discriminant analysis using the antioxidant data showed that the total proportion of correct placement was $>80 \%$ among the different regions of origin except for Sumatera (Table 6). The results of this study indicate that a combination of antioxidant testing, comparative 

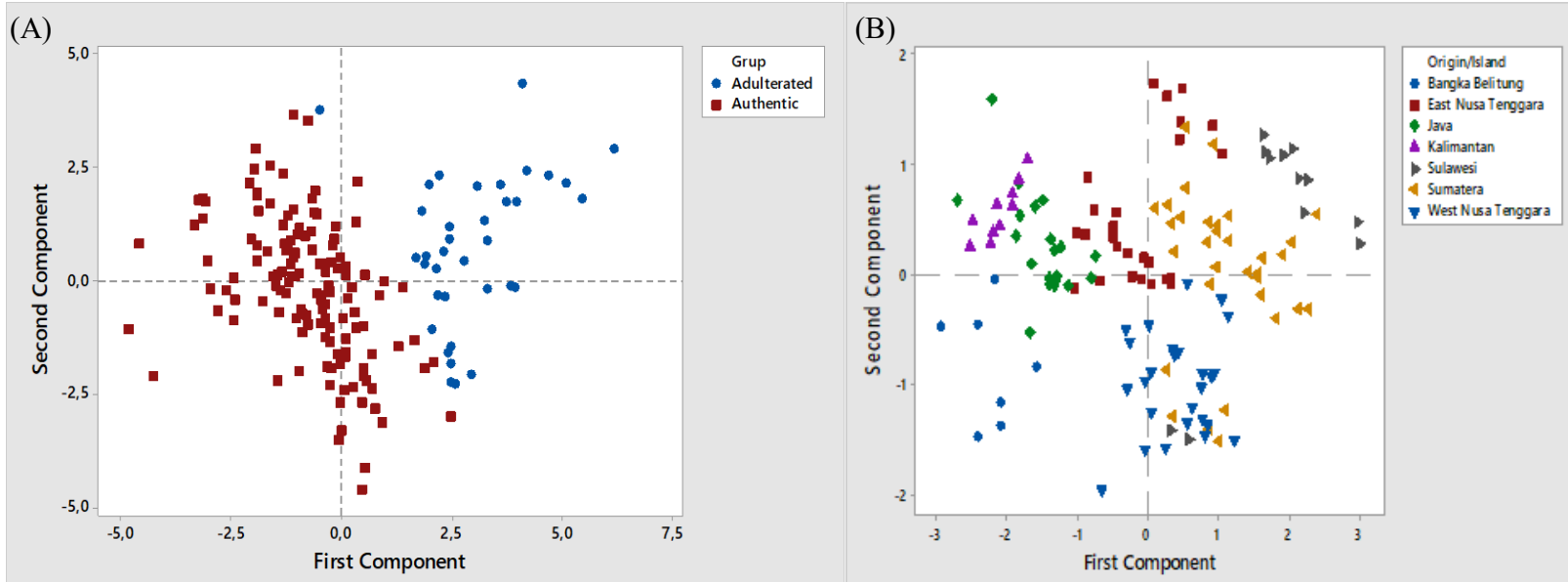

Figure 3. (A) Scatter plot of the PCA scores of authentic and adulterated Indonesia wild honey obtained from sugar content 2. (B) Scatter plot of the PCA scores of Indonesia wild honey based on geographical region obtained from antioxidant data analysis.

Table 6. Discriminant analysis with cross-validation for antioxidant properties of Indonesia wild honey

\begin{tabular}{lccccccc}
\hline \multirow{2}{*}{ Put into Group } & \multicolumn{7}{c}{ True Groups } \\
\cline { 2 - 8 } & $\begin{array}{c}\text { Bangka } \\
\text { Belitung }\end{array}$ & Kalimantan & Sulawesi & Sumatera & $\begin{array}{c}\text { West Nusa } \\
\text { Tenggara }\end{array}$ & $\begin{array}{c}\text { Eat Nusa } \\
\text { Tenggara }\end{array}$ & Java \\
\hline Bangka Belitung & 6 & 0 & 0 & 0 & 0 & 0 & 0 \\
Java & 0 & 0 & 0 & 0 & 0 & 4 & 16 \\
Kalimantan & 1 & 10 & 0 & 0 & 0 & 0 & 4 \\
West Nusa Tenggara & 0 & 0 & 2 & 5 & 25 & 0 & 0 \\
East Nusa Tenggara & 0 & 0 & 0 & 6 & 0 & 22 & 0 \\
Sulawesi & 0 & 0 & 10 & 8 & 0 & 0 & 0 \\
Sumatera & 0 & 0 & 0 & 14 & 2 & 0 & 0 \\
Total N & 7 & 10 & 12 & 33 & 27 & 26 & 20 \\
N correct & 6 & 10 & 10 & 14 & 25 & 22 & 16 \\
Proportion & 0.857 & 1 & 0.833 & 0.424 & 0.926 & 0.846 & 0.8 \\
\hline
\end{tabular}

analysis, and chemometrics evaluation can provide basic information to the phytochemist before the identification and characterization of honey from various sources (Beretta et al., 2005).

\section{Conclusion}

This study evaluated IWH samples collected from seven different regions in Indonesia based on their physicochemical characteristics, sugar mineral content, and antioxidant properties. The results provide an overview of variations between the areas of origin. The moisture content ranged from $20.32 \%$ to $31 \%$, pH ranged from 3.08 to 4.65 , and the color ranged from yellow to amber tone. Some minerals were specific in several regions, but potassium was found and predominant in all honey types. Fructose and glucose were the more dominant sugars than sucrose, and these properties can be used to distinguish between authentic and adulterated honey samples by conducting multivariate analysis, PCA, and discriminant analysis. The antioxidant properties showed a correlation to the geographical origin, and grouping visualization can be made using PCA. Discrimination analysis using these parameters give accuracy $>80 \%$ among regions, except Sumatera island.

\section{Conflict of interest}

The authors declare that no conflict of interest.

\section{Acknowledgments}

The authors would like to thank the Indonesia Food and Drug Authority/ Badan Pengawas Obat dan Makanan (BPOM) for their financial support. Hermanto of Indonesia Wild Honey Network (IWHN)/Jaringan Madu Indonesia (JMHI), Budi Aulia and Afri Yondra of WWF Indonesia, Riau Program, Bahrizon of Riau beekeepers, Eman Sulaeman of Koperasi Hanjuang, Banten, Novemris Tefa, Matheos Anin, Manason Nubatonis and Asbanu Nicodemus of Gunung Mutis National Park, Anis Hayong of Rumadu, Flores, Rini Umiyati of UPGRIS Univ, Semarang, Ika Mulyaningsih and Abdul Aris from Sumbawa, Jalisman of Waslit, North Luwu, Tri Astuti Rahmawati from BPOM provincial office in Bangka Belitung, Yudadi Bina Mulya TN and Kristiorini Dwi Nursanti from Central Sulawesi for supplying honey samples. 


\section{References}

Ajtony, Z., Bencs, L., Haraszi, R. and Szoboszlai, N. (2007). Study on the simultaneous determination of some essential and toxic trace elements in honey by multi-element graphite furnace atomic absorption spectrometry. Talanta, 71(2), 683-690. https:// doi.org/10.1016/j.talanta.2006.05.023

Al-Waili, N., Salom, K., Al-Ghamdi, A., Ansari, M.J., Al-Waili, A. and Al-Waili, T. (2013). Honey and cardiovascular risk factors, in normal individuals and in patients with diabetes mellitus or dyslipidemia. Journal of Medicinal Food, 16(12), 1063-1078. https://doi.org/10.1089/jmf.2012.0285

Alqarni, A.S., Owayss, A.A., Mahmoud, A.A. and Hannan, M.A. (2014). Mineral content and physical properties of local and imported honeys in Saudi Arabia. Journal of Saudi Chemical Society, 18(5), 618-625. https://doi.org/10.1016/j.jscs.2012.11.009

Alvarez-Suarez, J.M., Tulipani, S., Romandini, S., Bertoli, E. and Battino, M. (2010). Contribution of honey in nutrition and human health: A review. Mediterranean Journal of Nutrition and Metabolism, 3(1), 15-23. https://doi.org/10.1007/s12349-0090051-6

Alves, A., Ramos, A., Gonçalves, M.M., Bernardo, M. and Mendes, B. (2013). Antioxidant activity, quality parameters and mineral content of Portuguese monofloral honeys. Journal of Food Composition and Analysis, 30(2), 130-138. https:// doi.org/10.1016/j.jfca.2013.02.009

Ball, D.W. (2007). The Chemical Composition of Honey. Journal of Chemical Education, 84(10), 1643. https://doi.org/10.1021/ed084p1643

Batista, B.L., da Silva, L.R.S., Rocha, B.A., Rodrigues, J.L., Berretta-Silva, A.A., Bonates, T.O., Gomes, V.S.D., R.M.Barbosa, R.M. and Barbosa, F. (2012). Multi-element determination in Brazilian honey samples by inductively coupled plasma mass spectrometry and estimation of geographic origin with data mining techniques. Food Research International, 49(1), 209-215. https:// doi.org/10.1016/j.foodres.2012.07.015

Beretta, G., Granata, P., Ferrero, M., Orioli, M. and Maffei Facino, R. (2005). Standardization of antioxidant properties of honey by combination of spectrophotometric/fluorimetric assays and chemometrics of spectrophotometric/fluorimetric assays and chemometrics. Analytica Chimica Acta, 533(2), 185-191. https://doi.org/10.1016/ j.aca.2004.11.010

Bertoncelj, J., Doberšek, U., Jamnik, M. and Golob, T.
(2007). Evaluation of the phenolic content, antioxidant activity and colour of Slovenian honey. Food Chemistry, 105(2), 822-828. https:// doi.org/10.1016/j.foodchem.2007.01.060

Bogdanov, S. and Martin, P. (2002). Honey authenticity: a review. Swiss Bee Research Centre, p. 1-20. Retreived from bee-hexagon website: http:// www.bee-hexagon.net/files/file/fileE/Honey/ AuthenticityRevue_Internet.pdf

Horn, H. (2013). Honey in medicine. Dtsch Med Wochenschr, 138(51/52), 2647-2652. https:// doi.org/10.1055/s-0033-1359950

Bogdanov, S. (2009). Harmonised Methods of the International International Honey Commission. Retreived from bee-hexagon website: http://www.ihc -platform.net/ihcmethods2009.pdf

Bogdanov, S., Ruoff, K. and Oddo, L.P. (2004). Physicochemical methods for the characterisation of unifloral honeys : a review. Apidologie, 35(Suppl. 1), 4-17. https://doi.org/10.1051/apido:2004047

Boussaid, A., Chouaibi, M., Rezig, L., Hellal, R., Donsì, F., Ferrari, G. and Hamdi, S. (2018). Physicochemical and bioactive properties of six honey samples from various floral origins from Tunisia. Arabian Journal of Chemistry, 11(2), 265274. https://doi.org/10.1016/j.arabjc.2014.08.011

Corbella, E. and Cozzolino, D. (2006). Classification of the floral origin of Uruguayan honeys by chemical and physical characteristics combined with chemometrics. LWT - Food Science and Technology, 39(5), 534-539. https://doi.org/10.1016/ j.lwt.2005.03.011

Silva, P.M.D., Gauche, C., Gonzaga, L.V., Costa, A.C.O. and Fett, R. (2016). Honey: Chemical composition, stability and authenticity. Food Chemistry, 196, 309323. https://doi.org/10.1016/j.foodchem.2015.09.051

Downey, G. and Kelly, J.D. (2006). Food Authentication using Infrared Spectroscopic Methods. Dublin, Ireland: Ashtown Food Research Centre.

El-Haskoury, R., Kriaa, W., Lyoussi, B. and Makni, M. (2018). Ceratonia siliqua honeys from Morocco: Physicochemical properties, mineral contents, and antioxidant activities. Journal of Food and Drug Analysis, 26(1), 67-73. https://doi.org/10.1016/ j.jfda.2016.11.016

Escuredo, O., Fernández-González, M., RodríguezFlores, M.S., Seijo-Rodríguez, A. and Seijo-Coello, M. C. (2013). Influence of the Botanical Origin of Honey from North Western Spain in Some Antioxidant Components. Journal of Apicultural Science, 57(1), 5-14. https://doi.org/10.2478/jas2013-0001 
Gallardo-Velázquez, T., Osorio-Revilla, G., Loa, M.Z.D. and Rivera-Espinoza, Y. (2009). Application of FTIR-HATR spectroscopy and multivariate analysis to the quantification of adulterants in Mexican honeys. Food Research International, 42(3), 313318. https://doi.org/10.1016/j.foodres.2008.11.010

Gámbaro, A., Ares, G., Giménez, A. and Pahor, S. (2007). Preference mapping of color of Uruguayan honeys. Journal of Sensory Studies, 22(5), 507-519. https://doi.org/10.1111/j.1745-459X.2007.00125.x

Guler, A., Bakan, A., Nisbet, C. and Yavuz, O. (2007). Determination of important biochemical properties of honey to discriminate pure and adulterated honey with sucrose (Saccharum officinarum L.) syrup. Food Chemistry, 105(3), 1119-1125. https:// doi.org/10.1016/j.foodchem.2007.02.024

Ioannidou, M.D., Zachariadis, G.A., Anthemidis, A.N. and Stratis, J.A. (2005). Direct determination of toxic trace metals in honey and sugars using inductively coupled plasma atomic emission spectrometry. Talanta, 65(1), 92-97. https:// doi.org/10.1016/j.talanta.2004.05.018

James, O.O., Mesubi, M.A., Usman, L.A., Yeye, S.O., Ajanaku, K.O., Ogunniran, K.O., Ajani, O.O. and Siyanbola, T. O. (2009). Physical characterisation of some honey samples from North-central Nigeria. International Journal of Physical Sciences, 4(9), 464 -470 .

Kamal, M.A. and Klein, P. (2011). Determination of sugars in honey by liquid chromatography. Saudi Journal of Biological Sciences, 18(1), 17-21. https:// doi.org/10.1016/j.sjbs.2010.09.003

Karabagias, I. K., Badeka, A., Kontakos, S., Karabournioti, S. and Kontominas, M.G. (2014). Characterisation and classification of Greek pine honeys according to their geographical origin based on volatiles, physicochemical parameters and chemometrics. Food Chemistry, 146, 548-557. https://doi.org/10.1016/j.foodchem.2013.09.105

Kaškoniene, V. and Venskutonis, P.R. (2010). Floral Markers in Honey of Various Botanical and Geographic Origins: A Review. Comprehensive Reviews in Food Science and Food Safety, 9(6), 620 -634 . https://doi.org/10.1111/j.15414337.2010.00130.x

Kuś, P.M., Jerković, I., Tuberoso, C.I.G., Marijanović, Z. and Congiu, F. (2014). Cornflower (Centaurea cyanus L.) honey quality parameters: Chromatographic fingerprints, chemical biomarkers, antioxidant capacity and others. Food Chemistry, 142, $\quad 12-18 . \quad \mathrm{https} / / /$ doi.org/10.1016/ j.foodchem.2013.07.050
Lachman, J., Orsák, M., Hejtmánková, A. and Kovářová, E. (2010). Evaluation of antioxidant activity and total phenolics of selected Czech honeys. LWT Food Science and Technology, 43(1), 52-58. https:// doi.org/10.1016/j.lwt.2009.06.008

Ma, T., Zhao, H., Liu, C., Zhu, M., Gao, H., Cheng, N. and Cao, W. (2019). Discrimination of natural mature acacia honey based on multiphysicochemical parameters combined with chemometric analysis. Molecules, 24(14), 16-19. https://doi.org/10.3390/molecules24142674

Nalda, M.J.N., Yagüe, J.L.B., Diego Calva, J.C. and Gómez, M.T.M. (2005). Classifying honeys from the Soria Province of Spain via multivariate analysis. Analytical and Bioanalytical Chemistry, 382(2), 311 -319. https://doi.org/10.1007/s00216-005-3161-0

Pereira, V., Pontes, M., Câmara, J.S. and Marques, J.C. (2008). Simultaneous analysis of free amino acids and biogenic amines in honey and wine samples using in loop orthophthalaldeyde derivatization procedure. Journal of Chromatography A, 1189(12), 435-443. https://doi.org/10.1016/ j.chroma.2007.12.014

Pohl, P. (2009). Determination of metal content in honey by atomic absorption and emission spectrometries. TrAC - Trends in Analytical Chemistry, 28(1), 117128. https://doi.org/10.1016/j.trac.2008.09.015

Riswahyuli, Y., Rohman, A., Setyabudi, F.M.C.S. and Raharjo, S. (2019). Evaluation of Phenolic Content and Free Radical Scavenging Activity of Indonesia Wild Honey Collected from Seven Different Regions. Journal of Food Research, 8(6), 94-103. https://doi.org/10.5539/jfr.v8n6p94

Sahinler, N., Sahinler, S. and Gul, A. (2004). Biochemical composition of honeys produced in Turkey. Journal of Apicultural Research, 43(2), 5356. https:// doi.org/10.1080/00218839.2004.11101110

Saranraj, P. and Sivasakthi, S. (2018). Comprehensive Review on Honey: Biochemical and Medicinal Properties. Journal of Academia and Industrial Research, 6(10), 165-181.

Sari, R.K. and Bertoni, R. (2014). Kajian Manfaat Madu hutan Anggota JMHI terhadap Penyakit Kanker dan Anti Aging. Indonesia: Jaringan Madu Hutan Indonesia. [In Bahasa Indonesia].

Sarwono, B. (2003). Kiat Mengatasi Permasalahan Praktis Lebah Madu. 3rd ed. Jakarta, Indonesia: PT. Agromedia Pustaka. [In Bahasa Indonesia].

Siddiqui, A.J., Musharraf, S.G., Choudhary, M.I. and Rahman, A.-U. (2017). Application of analytical methods in authentication and adulteration of honey. 
Food Chemistry, 217, 687-698. https:// doi.org/10.1016/j.foodchem.2016.09.001

Silici, S., Uluozlu, O.D., Tuzen, M. and Soylak, M. (2008). Assessment of trace element levels in Rhododendron honeys of Black Sea Region, Turkey. Journal of Hazardous Materials, 156(1-3), 612-618. https://doi.org/10.1016/j.jhazmat.2007.12.065

Sivakesava, S. and Irudayaraj, J. (2001). Prediction of Inverted Cane Sugar Adulteration of Honey by Fourier Transform Infrared Spectroscopy. Journal of Food Science: Food Engineering and Physical Properties, 66(7), 972-978. https://doi.org/10.1111/ j.1365-2621.2001.tb08221.x

Soares, S., Amaral, J.S., Oliveira, M.B.P.P. and Mafra, I. (2017). A Comprehensive Review on the Main Honey Authentication Issues: Production and Origin. Comprehensive Reviews in Food Science and Food Safety, 16(5), 1072-1100. https:// doi.org/10.1111/1541-4337.12278

Socha, R., Juszczak, L., Pietrzyk, S., Gałkowska, D., Fortuna, T. and Witczak, T. (2011). Phenolic profile and antioxidant properties of Polish honeys. International Journal of Food Science and Technology, 46(3), 528-534. https://doi.org/10.1111/ j.1365-2621.2010.02517.x

Tuberoso, C.I.G., Jerković, I., Sarais, G., Congiu, F., Marijanović, Z. and Kuś, P.M. (2014). Color evaluation of seventeen European unifloral honey types by means of spectrophotometrically determined CIE $\mathrm{L}^{*} \mathrm{C} *$ ab $\mathrm{h} * \mathrm{ab}$ chromaticity coordinates coordinates. Food Chemistry, 145, 284 291. https://doi.org/10.1016/j.foodchem.2013.08.032

Yücel, Y. and Sultanoğlu, P. (2013). Characterization of honeys from Hatay Region by their physicochemical properties combined with chemometrics. Food Bioscience, 1, 16-25. https://doi.org/10.1016/ j.fbio.2013.02.001

Zhou, F., Peng, J., Zhao, Y., Huang, W., Jiang, Y., Li, M., Wu, X. and Lu, B. (2017). Varietal classification and antioxidant activity prediction of Osmanthus fragrans Lour. flowers using UPLC-PDA/QTOFMS and multivariable analysis. Food Chemistry, 217, 490-497. https://doi.org/10.1016/ j.foodchem.2016.08.125 